\title{
STRATEGIC MANAGEMENT ACCOUNTING TOOLS AS A 'PACKAGE': A CASE STUDY
}

\author{
Hiruni Rathwatta ${ }^{1}$ and Tharusha Gooneratne ${ }^{2 *}$ \\ ${ }^{1}$ University of Colombo, Sri Lanka \\ ${ }^{2}$ Faculty of Management and Finance - Accounting, \\ University of Colombo, Sri Lanka
}

\begin{abstract}
Drawing empirical evidence from a telecommunications firm in Sri Lanka this paper reports on a case study of how strategic management accounting (SMA) tools form a package. We deployed the qualitative method and case study approach, and in-depth face-to-face interviews with key personnel engaged in the practice of SMA in the firm and reviewed documents to collect data. Our findings indicated that the firm used a bundle of SMA tools relating to competitors, customers, cost, and performance, essentially as a package. Findings further suggested that the use of SMA tools as a package gives rise to crucial implications in the form of interactions and contradictions, which were managed through reconciliation statements, analysis of variances, discussions, meetings, and informal communications. This research contributes to the management accounting literature by developing novel insights on the notion of 'SMA tools as a package'. From a theoretical stance, it offers a framework to explore SMA tools as a package, capitalising on prior literature and field data from the case study firm. It also provides learning points to practitioners regarding the simultaneous use of a collection of SMA tools as a 'package' to support organisational decision making.
\end{abstract}

Keywords: strategic management accounting, package, case study

\section{ARTICLE INFO}

\section{Article History:}

Received: 7 August 2020

Accepted: 3 June 2021

Published: 31 August 2021

* Corresponding Author: Tharusha Gooneratne. E-mail: tharushng@dac.cmb.ac.lk 


\section{INTRODUCTION}

Globalisation, technological advancements, and increased customer awareness have led to accelerated competition in the contemporary corporate landscape. Faced with such a scenario, business firms have realised the need for broad-based information spanning financial and non-financial, as well as internal and external considerations to facilitate managerial decision making. Traditional management accounting systems, however, have failed to provide such wide-ranging information, and this has led to a move from 'traditional' to 'strategic management accounting' (SMA) (Bromwich, 1990; Lord, 1996; Naranjo-Gil \& Hartman, 2007; Nixon, 2012a, 2012b).

The term SMA was first coined by Simmonds, and the initial definition dates back to 1981, which is "the provision and analysis of management accounting data about a business and its competitors, for use in developing and monitoring business strategy" (Simmonds, 1981, p. 26). Across time, there have been many writings on SMA, and a collection of contemporary approaches to management accounting has used the umbrella term, SMA. This includes activity-based costing (ABC), balanced scorecard (BSC), competitor analysis, customer profitability analysis (CPA), life cycle costing (LCC), target costing etc. These tools while carrying a strategic orientation, provide external information, outside the boundaries of a firm, relating to competitors, suppliers and customers, alongside traditional cost and financial performance data (Govindrajan, 1988; Guilding et al., 2000; Shank, 1989), and have been adopted by firms across different industries (Dixon \& Smith, 1993; Bromwich \& Bhimani, 1994; Roslender, 1995).

Although existing studies have provided important insights on these individual SMA tools, in practice, business organisations use a collection of such tools. Also, there is an upcoming trend calling for examining a combination of SMA tools simultaneously. For instance, Emblemsvag (2001) presented a new cost evaluation model combining ABC and LCC, namely activity-based life cycle costing, while Cardinaels et al. (2004) suggested future studies to explore how $\mathrm{ABC}$ costing interacts with other tools, and Siguenza-Guzman et al. (2016) noted the interrelationship between $\mathrm{ABC}$ and benchmarking. More importantly, building upon Brown (2005), Malmi and Brown (2008) espouse that management control systems (MCS) do not operate in isolation, instead as a package, and several subsequent 
studies have taken this path of the MCS package (Meer-Kooistra \& Scapens, 2008; O'Grady \& Akroyd, 2016; Sandelin, 2008). Addressing an apparent omission in the literature and extending these ideas to the arena of SMA, this paper explores how various SMA tools are configured as a package.

An initial discussion with a key informant of the case study firm (hereafter called as Telco PLC) suggested that it uses a collection of SMA tools for decision making. Therefore, this paper delves into how various SMA tools have manifested into a 'package' in Telco PLC, a firm in the telecommunications industry of Sri Lanka, which is subjected to stiff competition. More particularly, it addresses the following research questions: what are the SMA tools used in the case of the study firm? Do these various SMA tools form a package? and are there any implications of using SMA tools as a package? By doing so, the paper generates novel insights on the notion of 'package' in the realm of SMA tools and forms a useful addition to the current body of knowledge. From a theoretical stance, it offers a framework to explore SMA tools as a package in other firms and by doing so, responds to the call of Malmi and Granlund (2009) for practice-oriented research in the field of management accounting. By taking a broader package approach to the study SMA tools, the findings of this paper also offer learning points to practitioners on the simultaneous use of a range of SMA tools to support organisational decision making, while uncovering implications of using SMA tools as a 'package'.

The rest of the paper is structured as follows. Section two reviews prior SMA literature. Section three presents the research context, theory and the research method adopted. This is followed by the findings in section four, while section five presents a discussion of findings and concludes.

\section{REVIEW OF PRIOR LITERATURE}

\section{A Glimpse of SMA Research}

Although there is no one agreed definition of SMA, it can be broadly viewed as the use of management accounting information to support strategic decision-making (Tillmann \& Goddard, 2008). In her review paper, 'strategic management accounting: how far have we come in 25 years?' 
Langfield-Smith (2008a) espouses SMA as taking a strategic orientation to the generation, interpretation, analysis of management accounting information and competitors' activities, while Cinquini and Tenucci (2010) have identified SMA tools in the perspectives of cost, customer, competitor, and performance. The literature also suggests that while SMA takes different forms in different organisational contexts (Tillmann \& Goddard, 2008), the successful usage of SMA practices is reflected through the actions of top management and the presence of management accountants who possess skills to adapt SMA tools as suited to an organisation (Abdullah \& Said, 2015).

Various individual SMA tools such as ABC (Cunningham, 1992; Bjørnenak, 1997; Cardinaels et al., 2004; Schoute, 2011), LCC (Dunk, 2004; Higham et al., 2014; Spickova \& Myskovaa, 2015; Pasch, 2019), cost of quality (COQ) (Moon \& Bates, 1993; Roden \& Dale, 2000), benchmarking (Cadez \& Guilding, 2007; Hinton et al., 2000), target costing (Ellram, 2006; Yazdifar \& Askarany, 2012), customer accounting and customer profitability analysis (Mouritsen, 1997; Guilding \& McManus, 2002; Chen et al., 2014), competitor analysis (Guilding, 1999; Guilding et al., 2000; Bennett, 2003; Guo et al., 2017), BSC (Ax \& Bjørnenak, 2005; Butler et al., 1997; Papalexandris et al., 2004; Ferreira, 2017; Wickramasinghe et al., 2008) has been the focus of past researchers. Supplementing such work, the extant literature also carries studies focusing on the linkages among various tools. This includes the interplay between BSC and TQM (Hoque, 2003; Modell, 2009), linking target costing to other tools and processes (Ansari et al., 2007), combining quality cost measurements and accounting reports (Fons, 2012). Adding to this list is also a stream of ABC studies, such as the interconnection between $\mathrm{ABC}$ and benchmarking (Siguenza-Guzman et al., 2016), ABC and supply chain costing (Schulze et al., 2012), ABC and LCC (Emblemsvag, 2001) as well as value management and ABC (SalemMhamdia \& Ghadhab, 2012).

Next, we turn to how the notion of package has been used in relation to MCS and how SMA tools could form a package. 


\section{The Notion of MCS Package}

Taking the view that the MCS do not operate in isolation, Malmi and Brown (2008) advocated 'MCS as a package', and developed a framework comprising planning, cybernetics, reward and compensation, administrative and cultural controls. Following this, several management accounting researchers have adopted Malmi and Browns' typology. Accordingly, embracing the notion of the MCS package, research has also been founded upon output, behavioural and social controls in a lean manufacturing context (Kennedy \& Widener, 2008) as well as formal and informal controls (Strauss et al., 2013; Sandelin, 2008; Evans \& Tucker, 2015). The work of Strauss et al. (2013) through a qualitative cross-sectional field study explored a MCS package comprising of formal and informal controls in newly startup firms in Germany, identifying the reasons for introducing MCS and the reciprocity between the parts of the MCS package. Furthermore, Sandelin (2008) was founded upon cultural, personnel, action and results controls in the two perspectives, formal and informal in relation to a growth firm. Similarly, the work of Evans and Tucker (2015) premised on an Australian renewable energy company, explored how formal and informal control, operate as a package in response to organisational change arising from the introduction of the Clean Energy Act.

Adding to this burgeoning literature is the governance package for lateral relations comprising economic, institutional, social, and technical structures (Meer-Koositra \& Scapens, 2008) as well as an MCS package containing accounting, compensation, administrative and cultural controls (Bedford et al., 2016) in different strategic contexts such as defender and prospector. This is in the midst the work of Langfield-Smith (2008b) which illuminates that behaviour controls, output controls and social controls, formed part of the control package in a case study of a collaborative alliance in the construction industry. Besides, the link between profitability and SMA tools relating to cost, assets, and revenue in the Egyptian context has also been researched (Mohamed \& Jones, 2014).

These stream of studies while espousing that the MCS can be used as a package, note that what constitutes the package depends on the organisational requirement, as the effectiveness of the MCS package relies on the fit with the strategic context as well as with each component in the 
package (Bedford et al., 2016). Integration of the components of the MCS package (O'Grady \& Akroyd, 2016) and ensuring that the package works holistically and in terms of the differential functionality of individual tools therein (Speklé, 2001) is thus critical, for they do not operate in isolation (Chenhall, 2003). Building upon and extending these insights to the arena of SMA, this paper explores the use of SMA tools as a 'package', thereby adding to the growing line of SMA research.

\section{RESEARCH SITE, THEORY AND METHOD}

\section{Research Site}

Our research site, Telco PLC is a multinational telecommunications firm. It is one of the largest players in the highly competitive telecommunications industry of Sri Lanka which currently comprises of over 30 members [Telecommunications Regulatory Commission (TRC) of Sri Lanka, 2017]. Telco PLC was selected as a suitable site for this research, as it adopted a collection of SMA tools for managerial decision making to achieve a competitive edge, which became evident during an initial discussion with a manager of the firm.

Telco PLC has been steadily growing with technological advancements and is renowned as the trend setter in South Asian telecommunications sector for its innovative practices. Telco's parent company is one of the largest telecommunications companies in Asia and holds over $80 \%$ of controlling power in it. Telco which had commenced operations in Sri Lanka over two and half decades ago is registered as a public entity in the Colombo Stock Exchange. It provides employment opportunities to more than 4,000 employees directly, and supports the livelihoods of over 100,000 families indirectly, having a 10 million subscriber base with $97 \%$ coverage of the population across the country (Annual Report, Telco PLC, 2016). It has won numerous awards for customer service as well as quality management and has maintained its repute for instigating sound accountability and corporate governance practices. 


\section{Theoretical Lens}

What is typically considered as theory by management accounting researchers are meta-level conceptual systems or theoretical lens, such as institutional theory, structuration theory, actor-network theory that are largely imported from other fields (domains) such as economics, psychology, or sociology (Lukka \& Modell, 2017; Malmi \& Granlund, 2009). These are essentially theories about management accounting, rather than theories of management accounting (Humphrey \& Scapens, 1996). Supplementing this, in a particular domain (such as management accounting) there are theories involving a body of knowledge on a substantive topic area, such as management control, performance measurement, cost accounting, strategic management accounting which are important to this particular domain (Lukka \& Vinnari, 2014; Lukka \& Modell, 2017). The current paper subscribes to this view.

Accordingly, seeing from a managerial perspective, the role of theory is to explain management accounting issues of practical relevance to a broad audience, providing explanations on 'what' management accounting systems or tools to use, 'how' and in 'what circumstances' (Malmi \& Granlund, 2009). In relation to the current paper 'what' refers to the SMA tools used, such as ABC, BSC, competitor focused accounting, customer profitability analysis, target costing, benchmarking etc; 'how' involves the manner in which these tools are used (for instance as a package) for managerial decision-making, while managing the resulting implications; 'what circumstances' include, which array of SMA tools could be used as a package under what kind of strategic orientation, organisational setting and contextual influences. This paper offers a framework on 'SMA tools as a package' drawing from prior literature such as Cinquini and Tenucci (2010) as well as capitalising on field data from the case study firm, while being inspired by the work of Malmi and Brown (2008) on 'MCS as a package'. See Figure 1, which represents such a culmination of past literature and evidence from the field. 


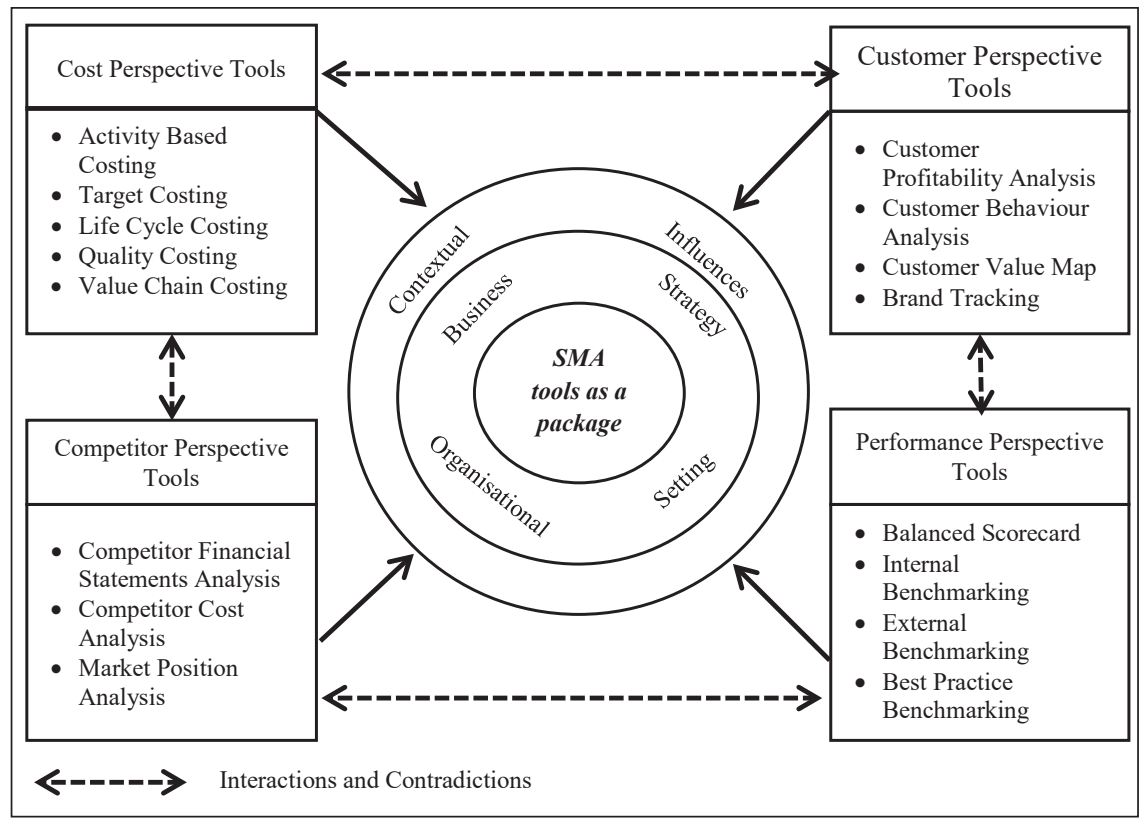

Figure 1: Framework for SMA Tools as A Package

\section{Research Method, Data Collection and Analysis}

To explore how SMA tools were used as a 'package' in the case study firm, this paper adopted the qualitative method and case study approach (Silverman, 2000; Mason, 2002; Yin, 2009). This research strategy appeared to be the most suitable, given the research questions of the study, which were: What are the SMA tools used in the case study firm? Do these various SMA tools form a package? Are there any implications of using the SMA tools as a package?

Data collection for this research was conducted mainly through indepth face-to-face interviews, using an interview guide (see Appendix A), followed by emerging questions for further understanding. The interviewees were selected based on purposive sampling ensuring the selection of the most information rich persons engaged in the practice of SMA in the firm (see Appendix B for the organisational structure and selected interviewees). Interview data was supplemented by analysis of documents, such as system generated and manual reports on SMA tools, printed copies of the SAP 
system and annual reports, which provided further evidence on the way SMA was packaged in the firm.

Data collection was done in two stages namely, a pilot study in November 2016 and a main study from January to May in 2017. The pilot study enabled us to obtain a general understanding of the nature of SMA practice in the firm. Three managers from corporate planning at the regional level were interviewed during this stage. It was found that while the corporate planning department played the main role, SMA tools were also handled by departments, such as corporate planning and corporate finance, as well as business units and regional branches, and that the firm used a bundle of SMA tools spanning customers, competitors, costs and performance. These initial discussions also revealed the existence of interactions and contradictions among various tools. The areas identified in the pilot study were deeply probed during the main study.

All in all, interviews were conducted with fourteen senior managers representing vital pillars in Telco PLC, such as corporate planning, corporate finance, business units and regional branches. Table 1 presents details of interviewees.

Table 1: Interviewee Details

\begin{tabular}{|c|c|c|c|c|c|c|}
\hline \multirow{2}{*}{ No } & \multirow{2}{*}{ Designation } & \multirow{2}{*}{ Department } & \multirow{2}{*}{$\begin{array}{l}\text { Duration of } \\
\text { interviews }\end{array}$} & \multicolumn{3}{|c|}{ Qualifications/professional background } \\
\hline & & & & $\begin{array}{c}\text { Basic } \\
\text { degree }\end{array}$ & $\begin{array}{c}\text { Post } \\
\text { graduate }\end{array}$ & Professional \\
\hline 1 & $\begin{array}{l}\text { Senior regional } \\
\text { manager }\end{array}$ & National sales & 45 minutes & Engineering & MBA & \\
\hline 2 & $\begin{array}{l}\text { General } \\
\text { manager }\end{array}$ & $\begin{array}{l}\text { Fixed and } \\
\text { broad band }\end{array}$ & 45 minutes & Engineering & MBA & CIMA \\
\hline 3 & Manager & $\begin{array}{l}\text { Corporate } \\
\text { planning } \\
\text {-regional }\end{array}$ & 40 minutes & Engineering & MBA & \\
\hline 4 & Head & $\begin{array}{l}\text { Business } \\
\text { transformation } \\
\text { and strategic } \\
\text { projects }\end{array}$ & 40 minutes & Engineering & & \\
\hline 5 & Senior manager & $\begin{array}{l}\text { Marketing } \\
\text { research }\end{array}$ & 50 minutes & Management & PhD & \\
\hline 6 & Group head & $\begin{array}{l}\text { Financial } \\
\text { accounting and } \\
\text { reporting }\end{array}$ & $\begin{array}{c}1 \text { hour and } 30 \\
\text { minutes }\end{array}$ & & MBA & CIMA \\
\hline
\end{tabular}




\begin{tabular}{|c|c|c|c|c|c|c|}
\hline \multirow{2}{*}{ No } & \multirow{2}{*}{ Designation } & \multirow{2}{*}{ Department } & \multirow{2}{*}{$\begin{array}{l}\text { Duration of } \\
\text { interviews }\end{array}$} & \multicolumn{3}{|c|}{ Qualifications/professional background } \\
\hline & & & & $\begin{array}{c}\text { Basic } \\
\text { degree }\end{array}$ & $\begin{array}{c}\text { Post } \\
\text { graduate }\end{array}$ & Professional \\
\hline 7 & Unit manager & $\begin{array}{l}\text { Corporate } \\
\text { finance and } \\
\text { reporting } \\
\text { (MA) }\end{array}$ & $\begin{array}{c}1 \text { hour and } 30 \\
\text { minutes }\end{array}$ & $\begin{array}{c}\text { BSc } \\
\text { Accounting }\end{array}$ & & \\
\hline 8 & Senior manager & $\begin{array}{l}\text { Corporate } \\
\text { finance }\end{array}$ & $\begin{array}{c}1 \text { hour and } 30 \\
\text { minutes }\end{array}$ & Engineering & MBA & CIMA \\
\hline 9 & Chief manager & $\begin{array}{l}\text { Human } \\
\text { resource } \\
\text { management } \\
(\mathrm{HRM})\end{array}$ & 45 minutes & HRM & MBA & $\mathrm{CIM}$ \\
\hline 10 & $\begin{array}{l}\text { Senior brand } \\
\text { manager }\end{array}$ & Marketing & 45 minutes & Engineering & & CIMA, CIM \\
\hline 11 & Chief manager & $\begin{array}{l}\text { Business } \\
\text { intelligence } \\
\text { analytics }\end{array}$ & 1 hour & Engineering & MBA & \\
\hline 12 & Chief manager & $\begin{array}{l}\text { Corporate } \\
\text { planning }\end{array}$ & 45 minutes & IT & MBA & $\mathrm{CIM}$ \\
\hline 13 & $\begin{array}{l}\text { Head - } \\
\text { corporate } \\
\text { planning }\end{array}$ & $\begin{array}{l}\text { Corporate } \\
\text { planning }\end{array}$ & 1 hour & Engineering & MBA & \\
\hline 14 & $\begin{array}{l}\text { Senior } \\
\text { manager- } \\
\text { corporate } \\
\text { planning }\end{array}$ & $\begin{array}{l}\text { Corporate } \\
\text { planning }\end{array}$ & $\begin{array}{c}1 \text { hour and } 15 \\
\text { minutes }\end{array}$ & Engineering & MBA & CIMA, CFA \\
\hline
\end{tabular}

The analysis of data was carried out based on thematic analysis (Braun $\&$ Clarke, 2013). Firstly, the interviews were transcribed into notes, then the transcribed notes of the interviews and documents were analysed to address the research questions. Thereafter codes were developed for similar ideas (themes), relating to the use of SMA tools as a package.

To ensure quality the following steps were undertaken. A substantial length of time was spent in the field conducting interviews (approximately 14 hours) and reviewing documents (around seven hours) over a period of six months. Further the interviewees were selected covering all departments relevant to SMA in the company to ensure an in-depth understanding of the practice. All interviews were recorded and transcribed verbatim. Data was also drawn from multiple sources, such as interviews and document analysis, which enabled data triangulation. This further enhanced the credibility of the findings. 


\section{FINDINGS}

This section illustrates the various SMA tools in Telco PLC and how they formed a 'package'. While the firm had used SMA tools since its inception in the early 1990s, across time the usage and scope had expanded amid the highly dynamic and competitive business environment faced, as well as the influence and knowledge of the top management. Therefore, SMA tools currently occupy a crucial position in Telco's corporate landscape.

\section{SMA Tools in Various Perspectives}

Ironically, although Telco PLC does not specifically use the term 'SMA', it used an array of SMA tools in par with the four dimensions identified by Cinquini and Tenucci (2010); customers, competitors, costs and performance, essentially forming a package. This is elaborated below.

Relating to the customer perspective, Telco PLC adopted several SMA practices which were prepared by the business intelligence department (under corporate planning), the management accounting department (under corporate finance), as well as the business units and regional branches, generated via the firm's MIS and dashboards. The chief manager of business intelligence espoused:

Basically, our department evaluate customers by checking their behaviour, revenue, usage, call time to identify selling opportunities. Another thing we do is dipstick survey from marketing perspective to analyse customer behaviour. We study about customers both quantitatively and qualitatively.

Several others reinforced the above. Further the Senior manager in marketing research and intelligence elaborated the use of the 'brand tracker' as a SMA tool to assess customer behaviour. As he added:

For customers, we do brand tracker to understand about brand performance, customer size, customer usage, customer perception and customer preference, and we do studies on brand usage, attitudes and their behaviours, all these are important things to predict the future. 
The Senior brand manager mentioned top of mind awareness (TOMA), as another tool under the customer perspective, which was used to evaluate the position of a brand in the mind of customers compared to competitors. In similar vein, the head - corporate planning shed light on the "customer value map" noting:

What is the value position to customers is one major concern for us. Value map is like a parameter for customers in their decision making, one thing is price; then convenience; availability; may be quality of service. We map our customer perspective and competitors. Then we can see whether our value proposition is stronger than the competitors.

The Senior Manager of Corporate Finance explained that his division analysed customer behaviour in specific situations, such as in reaction to tax changes, while the Manager of Corporate Planning (regional) described, "we look at the results and the market potential before and after launching a product. How the product is performing in the market and how to develop it to the next stage based on its life cycle."

As our field data also revealed, given the intense competition in the industry, under the competitor perspective Telco PLC engaged in competitor analysis based on financial statements, competitor cost analysis and market position analysis. The Head of Corporate Planning described stating:

We do a comparison on financial statements with competitors, based on their annual and quarterly reports. We get lot of things from these reports, like their revenue growth compared to our revenue growth and cost structures. Regarding competitor position we refer information published by the TRC, competitors' advertisements, newspaper articles.

Adding to this the Senior Manager of Corporate Finance explained:

Managers from corporate planning would have told you that they do competitor analysis. They focus more on customers, products, and strategy kind of thing. We are doing competitor analysis focusing more on financials. The usage of information is different in corporate planning and here. 
In the realm of cost, Telco used the $\mathrm{ABC}$, the $\mathrm{LCC}$, target costing, quality costing and value chain costing. As the Group Head of Financial Accounting and Reporting commented, the firm's ABC is a hybrid model of $\mathrm{ABC}$ and absorption costing, while the General Manager of Fixed and Broadband highlighted areas for development. He added:

We are using ABC. But there is room for improvement. Basically, corporate planning and corporate finance should drive it. Imean $A B C$ is not just allocating costs to different activities. There should be a visibility of how they allocate. As an example, for expenditures of a call centre; the cost pools should be identified based on actual costs. This is needed because of economic pressures. I highlighted this to the CFO and the team yesterday also.

Another SMA tool relating to the cost perspective visible in the firm was thes LCC, which was practiced through their own parameters. As the General Manager of Fixed and Broadband espoused, "we are not identifying cost of each product according to the theoretical LCC for introduction stage, maturity etc. We do a monthly performance review of each product based on a kind of profit and loss document." Various interviewees explained how the LCC was used in the decision-making process. For instance, the Chief Manager of Corporate Planning explained, "we use LCC to identify customer acquisition costs; marketing related cost, specific costs for mobiles, and for other products, such as TV connections, broadband etc". Adding to this, the Unit Manager for Management Accounting mentioned that the firm practices value chain costing, which is handled in combination by corporate planning and corporate finance. While the Senior Manager of Corporate Finance added, "we use value chain costing mostly to decide price of our products, like the price of $1 \mathrm{MB}$ of data is decided by value chain costing." Further, the Head of Corporate Planning outlined the use of quality costing stating, "in our case we monitor quality issues like, drop rates", in the meantime other interviewees pointed out to the use of target costing in pricing decisions.

Our findings suggested that the BSC and benchmarking were used as SMA tools under the performance perspective in Telco PLC. The BSC was particularly evident in the firm, stemming from the high interest placed on 
it by its first CEO. The Senior Manager of Corporate Planning explained how the firm's BSC was compared with that introduced by Kaplan and Norton (1992). As he said:

Our BSC is similar to the theory you learn. It was started here by our first CEO. What he told was a table has four legs, if one leg is missing, no point of the other three. He defined the four legs as value and profit, the financial perspective; market leadership, the customer perspective; product and quality leadership, the internal business process perspective; and lastly employees, which can be identified as learning and growth perspective.

The Chief Manager of Corporate Planning shed light on the firm's BSC stating, "we entered the industry with a vision and four diameters to look at operations. Everyone here has the four diameters in their mind. To monitor each diameter, we have different KPIs." Benchmarking was also an important SMA tool used by the firm under the performance perspective. In this regard Telco made extensive use of internal benchmarking, external benchmarking as well as best practice benchmarking. The Head of Corporate Planning explained stating:

We use benchmarking by measuring against targets, we do this with our sister companies and we compare with competition. We also compare against last year performance. Global benchmarking also we do. We are the number one in our country, so we are comparing with other number ones in regional countries, like India, Thailand, and Malaysia, Bangladesh, and practices of leading companies in other industries.

In the next section, we turned to how these multitude of SMA tools got translated as a package.

\section{SMA Tools as A 'Package'}

This section elaborates how the various SMA tools formed a package in Telco in terms of its constituents and uses, interactions as well as contradictions and organisational responses. 


\section{Constituents and Uses}

Given the multitude of tools falling under its banner, the SMA tools essentially formed a 'package' in Telco, as depicted in Table 2 and elaborated below.

Table 2: SMA Tools as A Package

\begin{tabular}{|c|c|c|c|c|}
\hline \multicolumn{5}{|c|}{ SMA Package } \\
\hline Perspective & $\begin{array}{c}\text { Customer } \\
\text { perspective }\end{array}$ & $\begin{array}{l}\text { Competitor } \\
\text { perspective }\end{array}$ & $\begin{array}{c}\text { Cost } \\
\text { perspective }\end{array}$ & $\begin{array}{l}\text { Performance } \\
\text { perspective }\end{array}$ \\
\hline \multirow{3}{*}{$\begin{array}{l}\text { Type of } \\
\text { information }\end{array}$} & Customer usage & $\begin{array}{l}\text { Competitor } \\
\text { position }\end{array}$ & Product cost & \multirow{3}{*}{$\begin{array}{l}\text { Internal and competitor } \\
\text { performance, } \\
\text { comparison with best } \\
\text { practices }\end{array}$} \\
\hline & $\begin{array}{l}\text { Customer } \\
\text { behaviour }\end{array}$ & $\begin{array}{l}\text { Competitor } \\
\text { cost }\end{array}$ & Activity cost & \\
\hline & $\begin{array}{l}\text { Customer } \\
\text { perception }\end{array}$ & $\begin{array}{l}\text { Competitor } \\
\text { performance }\end{array}$ & $\begin{array}{l}\text { Business } \\
\text { unit cost }\end{array}$ & \\
\hline \multirow{5}{*}{ SMA tools } & \multirow{2}{*}{$\begin{array}{l}\text { Customer } \\
\text { behaviour } \\
\text { analysis based } \\
\text { on dipstick } \\
\text { study }\end{array}$} & $\begin{array}{l}\text { Competitor } \\
\text { financial } \\
\text { statement } \\
\text { analysis }\end{array}$ & $\begin{array}{l}\text { Activity } \\
\text { based } \\
\text { costing }\end{array}$ & $\begin{array}{l}\text { Balanced } \\
\text { scorecard }\end{array}$ \\
\hline & & \multirow{2}{*}{$\begin{array}{l}\text { Market } \\
\text { position } \\
\text { analysis }\end{array}$} & $\begin{array}{l}\text { Life } \\
\text { cycle } \\
\text { costing }\end{array}$ & Internal benchmarking \\
\hline & $\begin{array}{l}\text { Brand } \\
\text { tracker }\end{array}$ & & $\begin{array}{l}\text { Target } \\
\text { costing }\end{array}$ & External benchmarking \\
\hline & \multirow{2}{*}{$\begin{array}{l}\text { Customer value } \\
\text { map and } \\
\text { Top of mind } \\
\text { awareness } \\
\text { (TOMA) }\end{array}$} & \multirow{2}{*}{$\begin{array}{l}\text { Competitor } \\
\text { cost } \\
\text { analysis }\end{array}$} & $\begin{array}{l}\text { Quality } \\
\text { costing }\end{array}$ & \multirow{2}{*}{$\begin{array}{l}\text { Best practice } \\
\text { benchmarking }\end{array}$} \\
\hline & & & $\begin{array}{l}\text { Value chain } \\
\text { costing }\end{array}$ & \\
\hline
\end{tabular}

As portrayed in Table 2, Telco's package of SMA tools consisted of tools across the four perspectives: customers, competitors, cost and performance. Dipstick study, focus group study, brand tracker, value map, and the TOMA under the customer perspective provided useful information on customer usage, behaviour and perception. Relating to the competitor perspective, the SMA tools such as competitor analysis based on financial statements, market position analysis and competitor cost analysis convey important insights on competitor position, cost, and performance. The ABC, the LCC, target costing, quality costing, and value chain costing as the SMA 
tools under the cost perspective, communicate costs of different products, activities, and business units. Adding to this, in the performance perspective; the BSC and the different types of benchmarking ranging from internal benchmarking to external benchmarking and best practice benchmarking offered performance indicators and information for performance evaluation purposes.

Various interviewees expressed how the package of the SMA tools provided information for managerial decision making. The Head of Corporate Planning espoused, "it's not a single thing. It's multiple things, depending on the decision". He further suggested: "I think if we can use the same package of information, it is better, like big data." The Group Head of Financial Accounting and Reporting noted, "these tools start from financial perspective and go down to continuous improvement. I don't think any South Asian company is having that kind of a link." Furthermore, the Senior Manager of Corporate Planning elaborated how a combination of information in different perspectives is generated for decision making via dashboards. He added:

Our department does a report called navigator which is prepared every month. So mobile business we have a navigator, then a separate navigator for each product. Navigators are based on BSC perspectives and captures information on financials, market, products and staff." BSC is a bible for us. When we report performance, we talk about the four dimensions. That is fundamental.

The Senior Manager of Corporate Finance noted the importance of using the SMA tools as a package, expressing:

For any decision, we should look from different perspectives and avoid silo thinking. Say from the sales guys' point of view, if they just look at gross new sales made, that's not enough. I think there should be a mechanism of linking all the perspectives of information for decision making.

In a similar vein, the Senior Manager of Marketing Research and Intelligence stressed the use of an SMA package in crafting and 
implementing strategies adding, "actually we are getting a direction from these tools. Top management is using this information heavily for different strategic decisions, such as product development, market focus etc." The Chief Manager of Business Intelligence Analytics, elaborated how the SMA information is circulated to managers, stating:

There is a system from MIS which provides information about customers, competitors, cost, and performance. Based on author level we share. We have to customise the different information to our environment. For example, relating to customers certain parameters are not relevant for decisions, it is different from business to business. Intelligence people need to identify proper combinations of these information.

The Manager of Corporate Planning (regional) noted: "we come to conclusions, based on all the sources not based on one." The Senior Regional Manager reiterated that while the firm used a package of SMA tools for decision making, its success depends on user knowledge. For the Senior Manager of Marketing Research and Intelligence, the usage of the SMA tools as a package and selection of the bundle of tools depended on each decision-making situation. He said, "actually it is based on your strategy, your requirement, right?" The Head of Business Transformation and Strategic Projects described how the SMA tools were used as a package in his area. He stated, "when we do a transformational process, we need information from all angles, customer, competitor, cost, and performance", while the Chief Manager of HRM shared his view stating, "the plus point is when you do more analysis with more tools your scorecard and performance will be comprehensive". While the Senior Brand Manager of Marketing espoused: "when we are using a collection of tools, it depends on many factors; availability of time, information and the nature of the product". Echoing similar sentiments, several other interviewees elaborated on the use of the SMA tools in identifying customer behaviour and competition as well as in guiding performance evaluation.

Using the SMA tools as a package in this manner, understandably give rise to implications in the form of interactions and contradictions. This is elaborated next. 


\section{Interactions among SMA Tools}

As our interviewees revealed interactions exist among the various SMA tools that form the package. The Head of Corporate Planning shed light on this adding:

There are inter-relationships; we refer to $A B C$ for other tools, like budgeting, benchmarking. If you take BSC and its financial part, our accounts show that this is our revenue. This gets linked with may be $A B C$ or LCC. For example, if our revenue is high, we know our income per subscriber will be high.

The Chief Manager of Corporate Planning too shared his views expressing, "there is a link; meaning in $\mathrm{ABC}$, quality costing, the costs are categorised based on the BSC perspectives." The Group Head of Financial Accounting and Reporting shared his idea on interactions between corporate planning, group finance and corporate finance. He added:

In my opinion, the ideal scenario is all these should come under finance department. Now it is separated because of the complexity of the business. Corporate planning and corporate finance departments are our nerve system.

While the Unit Manager of Management Accounting identified interactions between competitor information prepared by corporate planning and cost information prepared by corporate finance, the Senior Brand Manager of Marketing noted interactions among different tools stating that the Marketing Department refers to outcomes of business intelligence in preparation of reports. At the regional level, Telco PLC obtained competitor information from customers and compared such information with the competitor analysis done by corporate planning. The Senior Regional Manager expressed:

Corporate planning sends us information like monthly market share, and if there are any drastic changes in consumer behaviour they will tell in meetings. We see how IDD calls are behaving, which district is getting more IDD calls from which country. We also check whether our network is tallying with it. We are getting competitor information from customers also. 
Despite such interactions, contradictions were inevitable, as detailed below.

\section{Contradictions and Organisational Responses}

The words of interviewees reflected apparent contradictions that existed among the different SMA tools that formed a package in Telco. According to the Chief Manager of Corporate Planning, contradictions mainly arose due to the differences in the outlook of the various departments. As he espoused, "the marketing department identifies customers from the marketing point of view; finance department identifies customers from the financial point of view. Our perspectives are different." While the General Manager of Fixed and Broadband elaborated, "there are contradictions. We get different results from different departments; the intent is different. Anyway, it gives us the same picture from different lenses". On a similar tone, the Unit Manager in Management Accounting stated: "we sometimes get the same information, in different formats from two departments. One way it is time wasting, but probably, objective is different." Reinforcing the above, the Senior Manager of Corporate Finance explained, "the usage of information is different in different departments, for example corporate planning and here. If you take tax impact, corporate finance and corporate planning both do documents. But corporate planning does a general analysis using income statement and balance sheet, we do a detailed analysis".

Seen in this light, rather than being contradictions per se information may be duplicated, due to the differences in the viewpoint of various departments. The Senior Manager of Corporate Finance pointed out, "when our department and corporate planning prepare competitor analysis based on financial statements, there are duplications. But when the company is big, it is hard to do cross checking, and this is a public limited company, so corporate governance issue is also there, so segregation is better". The Senior Manager of Corporate Planning reiterated it, while the Group Head of Financial Accounting and Reporting added, "I think all these should come to single platform. It may be different departments, but we should have a holistic view. I do not see the synergy among these departments. He nevertheless added, "If you don't have arguments and contradictions, you cannot call it as a company. There will be arguments and conflicts, because with SMA, corporate planning does $60 \%$, business units $20 \%$, we 
do $10 \%$ and the regions remaining $10 \%$ ". The above interview evidence was corroborated through the review of documents.

Interviewees also espoused how deviations arise when information was extracted from different sources. The Chief Manager of Business Intelligence Analytics added, "sometimes management accounting says revenue is one thousand, but when we get from the source system of marketing, it may be more exact, one thousand one hundred."

The various SMA tools at Telco were used at different managerial levels and functions based on the needs and information availability. This invariably led to contradictions. Accordingly, discrepancies existed between corporate planning and regional level. At the regional level, demographic factors, IDD usage, and connecting countries were specifically considered. The Senior Regional Manager pinpointed:

Sometimes when we get information from different sources there are conflicts because of the different parties involved, like head office or regional level. I do the same kind of report at the regional level, and my answer may be different to the head office, because we are getting (competitor) information from our own area, from the customers.

He further added, "if the person who is using these tools doesn't have sufficient knowledge he cannot find the correct path in this information jungle". Knowledge disparity thus intensified conflicts. The Chief Manager of HRM highlighted a further problem encountered when information is provided as a package. He said, "when you get information in bulk sometimes information to your specific needs may not come up, and you cannot extract the correct information because there is lot of information, and some are not relevant for that specific situation".

Faced with such contradictions, Telco PLC employed different mechanisms as the Chief Manager of Corporate Planning noted, "when there are contradictions, we do reconciliations." He continued, "my suggestion is to have uniformity by collaborating everything into one system, one source of information, so that everybody is referring the same source". Several others reinforced the above, within this backdrop the Chief 
Manager of Business Intelligence Analytics espoused how contradictions were addressed. He said:

\begin{abstract}
If there is a mismatch between our records and management accounting department records, then we find the logic, we ask them for a breakdown. Certain things management accounting underestimates. We also do a breakdown and identify which are not matching, it is like a reconciliation.
\end{abstract}

The interviewees explained that alongside reconciliations, informal communication also took place among departments. As the Senior Manager of Corporate Finance noted, "sometimes not formal meetings it may be casual discussions to sort out differences, I call a senior manager in corporate planning, or he calls me." Several others reiterated how discussions are used to mitigate mismatches. Seen in this manner, reconciliations, variance analysis, meetings and informal discussions were deployed by Telco PLC to address contradictions between the various SMA tools.

\title{
DISCUSSION AND CONCLUSION
}

Amidst accelerated competition and varying customer preferences presentday organisations have moved towards SMA (Naranjo-Gil \& Hartman, 2007 ) in their quest for enhanced performance and better decision making (Chenhall \& Langfield-Smith, 2007). Similarly, Telco PLC exhibited a package consisting of a bundle of SMA tools.

Successful implementation of SMA tools is facilitated by the presence of managerial staff possessing such related knowledge (Tillmann \& Goddard, 2008), as reinforced through field data from Telco. Although a majority of Telco's managers are from an engineering background; through their postgraduate qualifications in business management and professional qualifications from the Chartered Institute of Management Accountants (CIMA) and Chartered Institute of Marketing (CIM) they have acquired knowledge on SMA tools. The literature suggests that the practice of SMA depends on the organisational context and could differ from the textbook form (Langfield-Smith, 2008a). On a comparable note, Telco practiced a mix of SMA tools, espoused in the literature as well as customised tools 
under the perspectives of customers, competitors, cost, and performance, developed as suited to the particular circumstances of the firm.

Keeping with the work of Guilding and McManus (2002), Telco adopted customer accounting tools focusing on customer behaviour, preference, usage, perception, size and brand performance. On the competitor front, in par with the literature which suggests that the use of competitor related information depended on company size, competitive strategy, and strategic mission (Guilding, 1999), amid the intense competition the case study firm used a range of SMA tools to assess competitor position, cost and performance. It carried out competitor analysis based on financial statement analysis (see Moon \& Bates, 1993), and used SMA tools in evaluating market conditions and competition, competitor strategies, brand positioning and in identifying opportunities in target markets (see Bennett, 2003). From the cost perspective, in line with the upcoming trend of integrating controls with quality and cost measurements systems (Fons, 2012), a collection of costing tools added to the package of SMA tools in Telco PLC. For instance, the $\mathrm{ABC}$ was prepared for costing and for evaluating different strategic projects, while being linked to benchmarking. The LCC facilitated decision making related to different strategic projects, while value chain costing was used in deciding prices and unit quantities. As for the performance perspective, it became apparent through field data, that a high emphasis was placed on the BSC, stemming from the strong influence of the former CEO. While the BSC may differ across organisations and countries due to variations in cultural, linguistic and human factors (Ax \& Bjørnenak, 2005), Telco had customised its BSC to suit its circumstances, in terms of perspective selection, while keeping with the essence of Kaplan and Norton's model. Accordingly, Kaplan and Norton's perspectives of financial, customer, internal business process and learning and growth were translated as value and profit, market leadership, product \& quality leadership and employee perspective, respectively.

While the BSC was claimed to be a strategic management tool for controlling as well as promoting strategic feedback and learning (Ferreira, 2017), Telco's BSC had become a tool for strategic information generation, being linked to other SMA tools, such as benchmarking (see Punniyamoorthy \& Murali, 2008). Benchmarking which is a popular tool for performance measurement (Hinton et al., 2000), carries an external as well 
as internal orientation focusing on organisational activities, functions, and operations to achieve continuous improvement (Kathleen et al., 1992). On a similar vein, Telco heavily used benchmarking, in comparing performance with the past year, leading and lagging competitors, market leaders in telecommunication in regional countries and sister companies in the group. Therefore, it exhibited the use of various strands of benchmarking, internal, external, and best practice.

An important deliberation emerging from our field data was that Telco PLC used an array of SMA tools, contented under the four perspectives: customers, competitors, cost, and performance forming a package. Amid the use of the SMA tools as a package, interactions were evident between tools such as the LCC, the BSC, benchmarking, the ABC and quality costing. While SMA work in the firm was handled by three departments; corporate planning, corporate finance and regional branches, segregation across different departments in this manner inherited advantages of integrity, transparency, and accountability. However, this is not without problems. Given the differences in the environment, data sources, focus, interpretation and knowledge gaps, disparities were visible between SMA reports generated by different departments, such as corporate planning and corporate finance as well as head office and the regional level. Having the expertise, the corporate planning division played a prominent role in the realm of SMA in Telco PLC. Nevertheless, reports prepared by them which took a rather organisational view were not fully appreciated by those at the regional level due to knowledge gaps and differences in focus. This was due to the regional level preparing their own reports using local data and claiming such reports to be more accurate than that produced by the head office. Originating from these differences, plausibly duplication of work, power struggles and conflicts existed among departments. While reconciliations, variance analysis, meetings and informal discussions were used as mechanisms to address contradictions, some managers concurred the need for a single platform for all SMA tools in the firm.

This paper contributes to literature, theory and practice. Considering that in practice, organisations use complex combinations of SMA tools which essentially constituted a package, through this paper we advanced the notion 'SMA tools as a package' adding to the current body of literature. This is important within a backdrop where most prior studies have been 
founded upon individual SMA tools. From a theoretical stance, this paper contributes to management accounting theory. Inspired by the MCS as a package as espoused by Malmi and Brown (2008) and other researchers taking a similar stance and extending this notion of 'package' to the realm of SMA, we offer a framework to explicate the SMA tools as a package drawing on prior literature such as Cinquini and Tenucci (2010) and capitalising on field data from the case study firm (see Figure 1). From a practical point of view, we shed light on how the various SMA tools can be packaged to facilitate organisational decision making, being mindful of capitalising on interactions and managing contradictions.

Our paper opens up opportunities for future research as well. The SMA is an under-researched area and potential researchers are inspired to apply this framework in examining the practice of the SMA tools as a package in organisations in different countries, industries, and settings. The framework offered in Figure 1, while keeping with the common wisdom of the SMA, such as strategy orientation, internal/external focus and financial/non-financial inclusion (Dixon \& Smith, 1993) encompasses a bundle of tools packaged under the perspectives customer, competitor, cost, and performance (Cinquini \& Tenucci, 2010). However, the absence of a single definition on the SMA (Langfield Smith, 2008a), and its wide variation in practice, given that the SMA exists in different forms in different organisations, poses a difficulty in building a unified framework. Further, while an array of tools could be taken under the banner of the SMA, the environments within which contemporary organisations operate are in a state of constant change. It is thus important to note that only general prescriptions could be made, and we do not assume the existing configuration as optimal. Therefore, one needs to be mindful of an organisation's business strategy, particular organisational setting within which the SMA tools operate, while comprehending their evolving nature as well as the contextual influences encountered by the firm (which stem from the broader environment based on the industry in which it operations, customers served and the nature of competition). This suggests that multifaceted considerations govern how the SMA tools are used as a package in an organisation. As depicted in Figure 1, the various SMA tools (under the different perspectives) being highly inter-linked, invariably gives rise to interactions and contradictions. Thus, which SMA tools in a package have the best fit, whether certain configurations systematically exist in particular settings, and how are SMA 
packages framed amidst organisational strategies, setting and the contextual influences encountered are worthy of inquiry. We leave such endeavours for future researchers and concur that this would be a fruitful way in developing a cumulative body of knowledge on the SMA tools as a package.

\section{REFERENCES}

Abdullah, N., \& Said, J. (2015). Enhancing the governance of government linked companies via strategic management accounting practices and value creation. Procedia Economics and Finance, 28, 222-229.

Ansari, S., Bell, J., \& Okano, H. (2007). Target costing: Uncharted research territory. Handbook of Management Accounting Research, 2, 507-530.

Ax, C., \& Bjørnenak, T. (2005). Bundling and diffusion of management accounting innovations - The case of the balanced scorecard in Sweden. Management Accounting Research, 16, 1-20.

Bedford, D., S., Malmi, T., \& Sandelin, M. (2016). Management control effectiveness and strategy: An empirical analysis of packages and systems. Accounting, Organizations and Society, 51, 12-28.

Bennett, R. (2003). Competitor analysis practices of British charities. Marketing Intelligence \& Planning, 21(6), 335-345.

Bjørnenak, T. (1997). Diffusion and accounting: The case of ABC in Norway. Management Accounting Research, 8, 3-17.

Braun, V., \& Clarke, V. (2013). Successful qualitative research: A practical guide for beginners. London: Sage.

Bromwich, M. (1990). The case for strategic management accounting: The role of accounting information for strategy in competitive markets. Accounting, Organizations and Society, 15(1/2), 27-46.

Bromwich, M., \& Bhimani, A. (1994). Management accounting pathways to progress. London: Chartered Institute of Management Accountants. 
Brown, D., A. (2005). Management control systems as a coupled package: An analytical framework and empirically grounded implications (Doctoral dissertation, University of Technology, Sydney).

Butler, A., Letza, S. R., \& Neale, B. (1997). Linking the balance scorecard to strategy. Journal of Long Range Planning, 30(2), 242-253.

Cadez, S., \& Guilding, C. (2007). Benchmarking the incidence of strategic management accounting in Slovenia. Journal of Accounting \& Organizational Change, 3(2), 126-146.

Cardinaels, E., Roodhooft, F., \& Warlop, L. (2004). The value of activitybased costing in competitive pricing decisions. Management Accounting Research, 16, 133-148.

Chen, C., X., Martin, M., \& Merchant, K., A. (2014). The effect of measurement timing on the information content of customer satisfaction measures. Management Accounting Research, 25(3), 187-205.

Chenhall, R. H., \& Langfield-Smith, K. (2007). Multiple perspectives of performance measures. European Management Journal, 25(4), 266-382.

Chenhall, R. H. (2003). Management control system design within its organisational context: Findings from contingency-based research and directions for the future. Accounting, Organizations and Society, 28(2-3), 127-168.

Cinquini, L., \& Tenucci, A. (2010). Strategic management accounting and business strategy: A loose coupling?. Journal of Accounting \& Organizational Change, 6(2), 228-259.

Cunningham, G., M. (1992). Management control and accounting systems under a competitive strategy. Accounting, Auditing \& Accountability Journal, 5(2), 85-102.

Dixon, R., \& Smith, D. (1993). Strategic management accounting. Omega, 21(6), 605-618. 
Dunk, A. S. (2004). Product life cycle cost analysis: The impact of customer profiling, competitive advantage, and quality of IS information. Accounting, Organizations and Society, 15, 401-414.

Ellram, L. M. (2006). The implementation of target costing in the United States: Theory versus practices. Supply Chain Management, 42(1), 13-26.

Emblemsvag, J. (2001). Activity-based life-cycle costing. Managerial Auditing Journal, 16(1), 17-27.

Evans, M., \& Tucker, B. P. (2015). Unpacking the package: Management control in an environment of organizational change. Qualitative Research in Accounting and Management, 12(4), 346-376.

Ferreira, A. M. S. C. (2017). How managers use the balanced scorecard to support strategy implementation and formulation processes. Review of Applied Management Studies, 15(1), 2-15.

Fons, L. A. S. (2012). Integration of quality cost and accounting practices. Total Quality Management Journal, 24(4), 338-351.

Govindarajan, V. (1988). A contingency approach to strategy implementation at the business-unit level: Integrating administrative mechanisms with strategy. The Academy of Management Journal, 31, 828-853.

Guilding, C. \& McManus, L. (2002). The incidence, perceived merit, and antecedents of customer accounting: An exploratory note. Accounting, Organizations and Society, 27, 45-59.

Guilding, C. (1999). Competitor-focused accounting: An exploratory note. Accounting, Organizations and Society, 24, 583-595.

Guilding, C., Cravens, K. S., \& Tayles, M. (2000). An international comparison of strategic management accounting practices. Management Accounting Research, 11(1), 113-135.

Guo, L., Sharma, R., Yin, L., Lu, R., \& Rong, K. (2017). Automated competitor analysis using big data analytics: Evidence from the fitness 
mobile app business. Business Process Management Journal, 23(3), 735-762.

Higham. A., Fortune, C., \& James, H. (2014). Life cycle costing: Evaluating its use in UK practice. Journal of Structural Survey, 33(1), 73-87.

Hinton, M., Francis, G., \& Holloway, J. (2000). Best practice benchmarking in the UK. International Journal of Benchmarking, 7(1), 52-61.

Hoque, Z. (2003). Total Quality Management and the balanced scorecards approach: A critical analysis of their potential relationships and directions of research. Critical Perspectives on Accounting, 14(5), 553-566.

Humphrey, C., \& Scapens, R. W. (1996). Methodological themes: Theories $\&$ case studies of organisational accounting practices: Limitations or liberation?. Accounting, Auditing \& Accountability Journal, 9(4),86106.

Kaplan, R., S., \& Norton, D. P. (1992). The balanced scorecard: Measures that drive performance. Harvard Business Review, 70(1), 71-79.

Kathleen, H., Liebfried, J., \& McNair, C. J. (1992). Benchmarking: A tool for continuous improvement. Human Resource management, Spring/ Summer, 31, 141-143.

Kennedy, F. A., \& Widener, S. K. (2008). A control framework: Insights from evidence on lean accounting. Journal of Management Accounting Research, 19, 301-323.

Langfield-Smith, K. (2008a). Strategic management accounting: How far have we come in 25 years?. Accounting, Auditing \& Accountability Journal, 21(2), 204-228.

Langfield-Smith, K. (2008b). The relations between transactional characteristics, trust and risk in the start-up phase of a collaborative alliance. Management Accounting Research, 19(4), 344-364. 
Lord, B. (1996). Strategic management accounting: The emperor's new clothes. Management Accounting Research, 7(3), 347-366.

Lukka, K., \& Modell, S. (2017). Interpretive research in accounting: Past, present and future. In Z. Hoque, L. D. Parker, M. A. Covaleski, \& K. Haynes (Eds.), The Routledge companion to qualitative accounting research methods (pp. 36-54). London: Routledge.

Lukka, K., \& Vinnari, E. (2014), Domain theory \& method theory in management accounting research. Accounting, Auditing \& Accountability Journal, 27(8), 1308-1338.

Malmi, T., \& Brown, D., A. (2008). Management control systems as a package - Opportunities, challenges and research directions. Management Accounting Research, 19, 287-300.

Malmi, T., \& Granlund, M. (2009). In search of management accounting theory. European Accounting Review, 18(3), 597-620.

Mason, J. (2002). Qualitative researching. Sage: London.

Meer-Kooistra, J. V., \& Scapens, R. W. (2008). The governance of lateral relations between within organizations. Management Accounting Research, 19, 365-384.

Modell, S. (2009). Bundling management control innovation: A field study of organizational experimenting with total quality management and the balance scorecard. Accounting, Auditing \& Accountability Journal, 22, 59-90.

Mohamed, A. A., \& Jones, T. (2014). Relationship between strategic management accounting techniques and profitability - A proposed model. Measuring Business Excellence, 18(3), 1 - 22.

Moon, P., \& Bates, K. (1993). Core analysis in strategic performance appraisal. Management Accounting Research, 4, 139-152. 
Mouritsen, J. (1997). Marginalizing the customer: Customer orientation, quality and accounting performance. Scandinavian Journal of Management, 13(1), 5-18.

Naranjo-Gil, D., \& Hartmann, F. (2007). Management accounting systems, top management team heterogeneity and strategic change. Accounting, Organizations and Society, 32, 735-756.

Nixon, B., \& Burns, J. (2012a). The paradox of strategic management accounting. Management Accounting Research, 23, 229-244.

Nixon, B., \& Burns, J. (2012b). Editorial Strategic management accounting. Management Accounting Research, 23, 225-228.

O'Grady, W., \& Akroyd, C. (2016). The MCS package in a non-budgeting organization: A case study of main freight. Qualitative Research in Accounting \& Management, 13(1), 2-30.

Papalexandris, A., Ioannou, G., \& Prastacos, G. (2004) Implementing the balanced scorecard in Greece: A software firm's experience. Journal of Long Range Planning, 37(4), 351-366.

Pasch, T. (2019). Organizational lifecycle and strategic management accounting. Journal of Accounting \& Organizational Change, 15(4), 580-604.

Punniyamoorthy, M., \& Murali, R. (2008). Balanced score for the balanced scorecard: A benchmarking tool. International Journal of Benchmarking, 15(4), 420-443.

Roden, S., \& Dale, B., G. (2000). Understanding the language of quality costing. Total Quality Management Magazine, 12(3), 179-185.

Roslender, R. (1995). Accounting for strategic positioning: Responding to the crisis in management accounting. British Journal of Management, $6(1), 45-57$. 
Salem-Mhamdia, A. B. H., \& Ghadhab, B. B. (2012). Value management and activity based costing model in the Tunisian restaurant. International Journal of Contemporary Hospitality Management, 24(2), 269-288.

Sandelin, M. (2008). Operation of management control practices as a package - A case study on control system variety in a growth firm context. Management Accounting Research, 19, 324-343.

Schoute, M. (2011). The relationship between product diversity, usage of advanced manufacturing technologies and activity-based costing adoption. Journal of British Accounting Review, 43, 120-134.

Schulze, M., Seuring S., \& Ewering, C. (2012). Applying activity-based costing in a supply chain environment. International Journal of Production Economics, 135, 716-725.

Shank, J. K. (1989). Strategic cost management: New wine, or just new bottles?. Journal of Management Accounting Research, 1, 47-65.

Siguenza-Guzman, L., Auquilla, A. Abbeele, A. V., \& Cattrysse, D. (2016). Using time-driven activity-based costing to identify best practices in academic libraries. Journal of Academic Librarianship, 2(3), 232-246.

Silverman, D. (2000). Doing qualitative research: A practical handbook. Thousand Oaks, CA: Sage.

Simmonds, K. (1981). Strategic management accounting. Management Accounting, 59(4), 26-30.

Speklé, R. F. (2001). Explaining management control structure variety: A transaction cost economics perspective. Accounting, Organizations and Society, 26(4-5), 419-441.

Spickova, M., \& Myskovaa, R. (2015). Costs efficiency evaluation using life cycle costing as strategic method. Procedia Economics and Finance, $34,337-343$. 
Strauss, E. R., Nevries, P., \& Weber, J. (2013). The development of MCS packages - Balancing constituents' demands. Journal of Accounting and Organizational Change, 9(2), 155-187.

Telco PLC Annual Report (2016). Telco. Sri Lanka.

Telecommunications Regulatory Commission of Sri Lanka. (2016). Available at: http://www.trc.gov.lk/2014-05-13-03-56-46/statistics. html.

Tillmann, K., \& Goddard, A. (2008). Strategic management accounting and sense-making in a multinational company. Management Accounting Research, 19, 80-102.

Wickramasinghe, D., Gooneratne, T., \& Jayakody, J. A. S. K. (2008). Interest lost: The rise and fall of a balanced scorecard project in Sri Lanka. Advances in Public Interest Accounting, 13, 237-271.

Yazdifar, H., \& Askarany, D. (2012). A comparative study of the adoption and implementation of target costing in the UK, Australia and New Zealand. International Journal of Production Economic, 135, 382-392.

Yin, R. K. (2009). Case study research: Design and methods (4 $4^{\text {th }}$ ed.). Thousand Oaks, USA: Sage. 


\section{APPENDIXES}

\section{Appendix A: Interview Guide}

\section{Personal information}

Name:

Department / Position:

Main tasks:

Academic/professional background:

\section{SMA Practices}

a) What are the various SMA tools used in the case study firm?

b) Customer perspective

i) What SMA tools and what information do you use for evaluating customers?

ii) How do you prepare such information?

iii) What are the benefits?

iv) Did you notice any drawbacks of it?

c) Competitor perspective

i) What SMA tools and what information do you use for evaluating competitors?

ii) How do you prepare such information?

iii) What are the benefits?

iv) Did you notice any drawbacks of it?

d) Cost perspective

i) What SMA tools and what information do you use for evaluating cost?

ii) How do you prepare such information?

iii) What are the benefits?

iv) Did you notice any drawbacks of it? 
e) Performance perspective

i) What SMA tools and what information do you use for evaluating performance?

ii) How do you prepare such information?

iii) What are the benefits?

iv) Did you notice any drawbacks of it?

\section{Managing different SMA tools}

a) Are you using outcomes of one tool as input for other tools?

b) Do you notice relationships among SMA tools?

c) Do you face any contradictions among tools? If so how do you manage it?

d) What suggestions do you have for further development of using these various tools? 


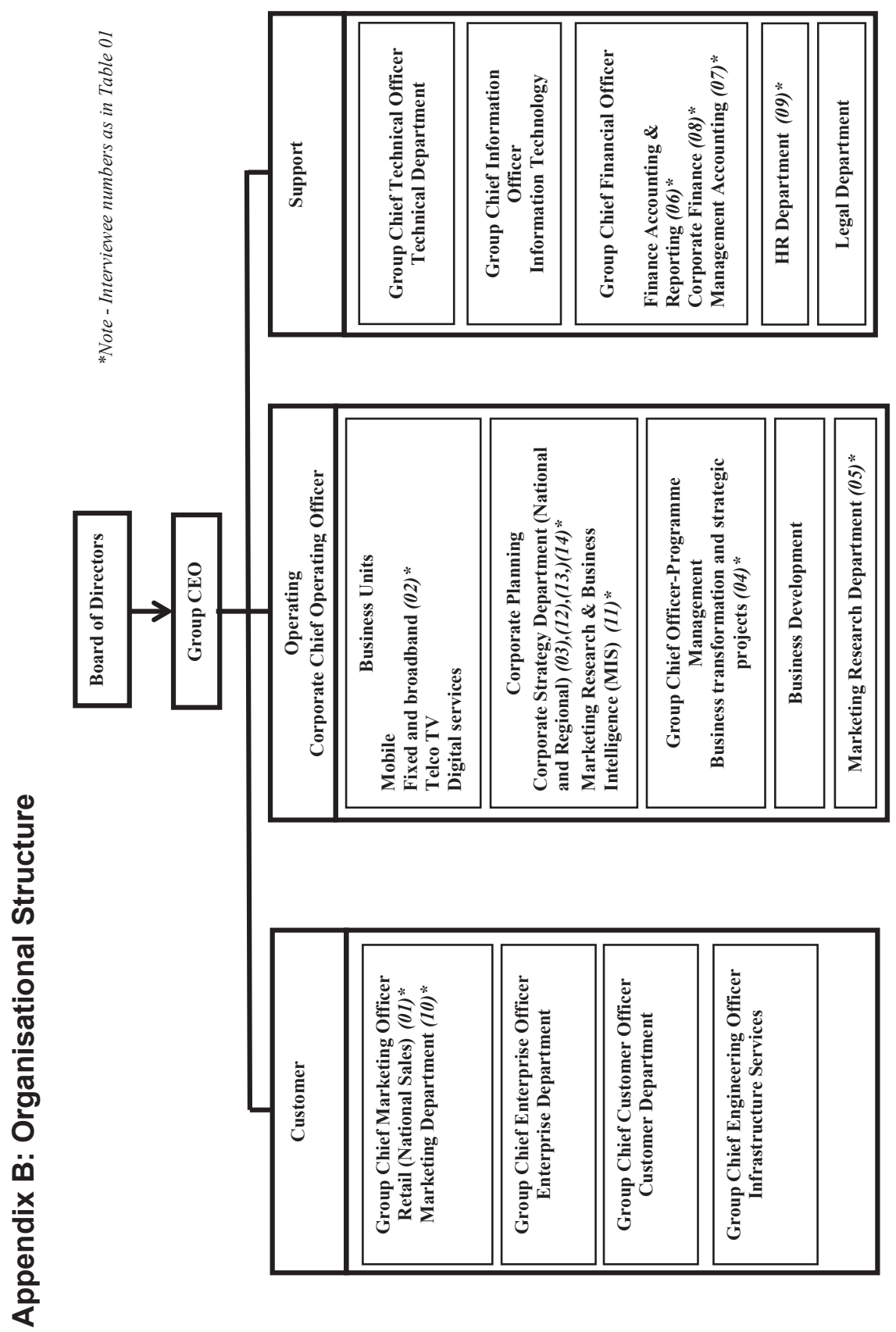

